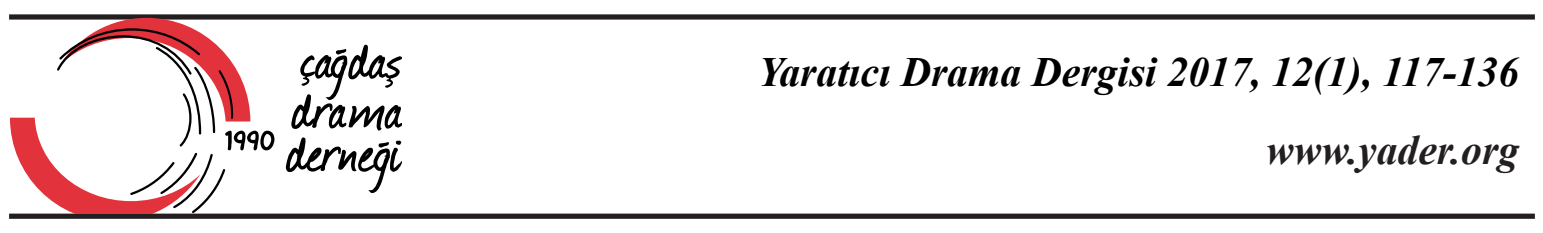

\title{
Yaratıcı Drama Lider ve Lider Adaylarının Ölçme ve Değerlendirme Konularındaki Profilleri ve Görüşleri
}

\author{
Erim Koçyiğit ${ }^{1}$
}

\begin{tabular}{|c|c|c|}
\hline \multicolumn{2}{|c|}{ Makale Bilgisi } & $\ddot{\mathbf{O} z}$ \\
\hline \multicolumn{2}{|c|}{ DOI: $10.21612 /$ yader.2017.007 } & Bu araştırmanın amacı; yaratıcı drama lider ve lider adaylarının yaratıcı \\
\hline \multicolumn{2}{|c|}{ Makale Geçmişi } & konularındaki profillerini ve yeterlilik algllarını belirlemektir. Araştırma, \\
\hline Geliş tarihi & 14.03.2017 & tarama desenindedir. Araștırmaya veri toplamak amacıla on iki sorudan \\
\hline Düzeltme & 20.03 .2017 & oluşan "Yaratıcı Drama Lider/Lider Adaylarının Ölçme ve Değerlendirme \\
\hline Kabul & 30.05 .2017 & $\begin{array}{l}\text { Konusundaki Görüşlerini Belirleme Anketi” geliştirilmiştir. Taslağl } 18 \\
\text { sorudan oluşan anket üçer ölçme değerlendirme uzmanı ve yaratıcı drama }\end{array}$ \\
\hline \multicolumn{2}{|c|}{ Anahtar Sözcükler } & $\begin{array}{l}\text { lider adayı tarafindan incelenmiş ve nihai } 12 \text { maddelik anket oluşturulmuştur. } \\
\text { Anketin kapsam geçerliği, üc avr ölçme değerlendirme uzmanından }\end{array}$ \\
\hline \multicolumn{2}{|c|}{ Yaratıcı drama } & görüş alınarak sağlanmıştır. Çevrimiçi olarak toplam 114 lider ve lider \\
\hline \multicolumn{2}{|l|}{ Ölçme } & adayına uygulanan anket sonucunda; lider ve lider adaylarının nicel veya \\
\hline \multicolumn{2}{|c|}{ Değerlendirme } & nitel araştırma yöntemleri konusunda eğitim aldıkları, yaratıcı drama \\
\hline \multicolumn{2}{|l|}{ Yeterlilik } & $\begin{array}{l}\text { atölyelerinde ă̆ırlıklı olarak sonuç değerlendirmeye yönelik olarak sözlü } \\
\text { değerlendirmeler yaptıkları, değerlendirme sonuçlarını genellikle kayıt altına } \\
\text { almadıkları ve büyük oranda katılımcıya geri bildirim vermedikleri, ölçme ve } \\
\text { değerlendirme konusunda yeterlilik algılarının orta düzey veya altında yer } \\
\text { aldı̆̆l görülmüştür. }\end{array}$ \\
\hline
\end{tabular}

\section{Profiles and Opinion of Creative Drama Leaders and Leading Candidates in Measurement and Evaluation}

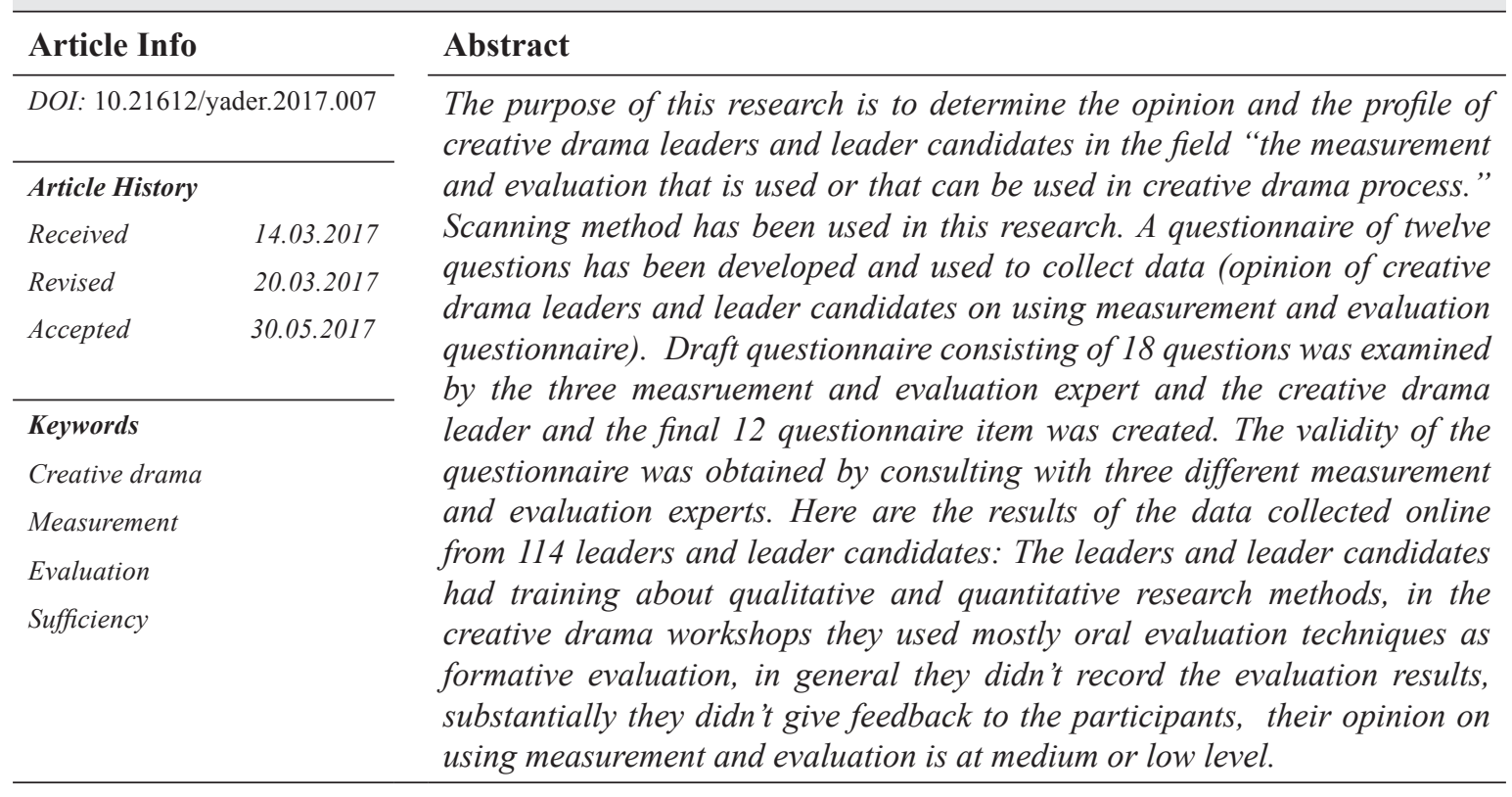

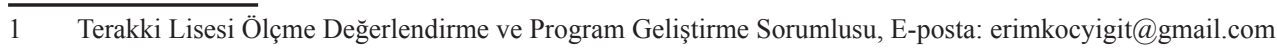




\section{Giriş}

Modern eğitim yaklaşımlarında ölçme ve değerlendirme sadece sürecin sonunda değil, süreç öncesinde ve/veya içerisinde her bir öğrenme biriminde işe koşulan, biçimlendirici, geliştirici ve tamamlayıcı bir mekanizma olarak kullanılmaktadır. Bu iki kavramdan ölçme; bir niteliğin gözlenip, gözlem sonuçlarının sayı veya sembollerle ifade edilmesidir (Turgut, 1997, s.12). Değerlendirme ise ölçme sonuçlarını bir ölçüte vurarak, ölçülen nitelik hakkında bir değer yargısına varılması sürecidir (Turgut, 1997, s.224). Bu noktada akla şu sorular gelmektedir: "Neyi gözlemlenmeli?" ve “Neden bir yargıya varılmalı?”. Ertürk (1972)'e göre, eğitim, "bireyin davranışlarında, kendi yaşantısı yoluyla ve kasıtlı olarak istendik yönde, kalıcı izli davranış değişikliği getirme süreci" olarak tanımlanmaktadır. Burada söz edilen kasıtlı ve istendik kavramları, eğitim sistemi içerisinde öğrenende gerçekleştirilmesi istenen değişikliğin ne olduğunu ifade etmektedir. Dolayısıyla gözlemlenmek istenen şey, bireyde gerçekleştirilmeye çalışılan "değişikliğin" kendisidir. "Neden bir yargıya varılmalı?" sorusu ise sistemin bütününü ilgilendiren bir durumdur. Çünkü sistem içerisinde, uygulayıcı (lider, öğretmen) bir takım değişimler yaratmak istemekte/yaratmakla görevlidir ve bunun için planlı ve organize girişimlerde bulunmaktadır. Sürecin öncesinde, içerisinde veya sonundaki ölçümlerinde bu değişimin gerçekleşme düzeyine ait bazı bulgulara rastlamayı beklemektedir. $\mathrm{Bu}$ noktada değişimin varlığı kadar yönü, büyüklüğü, şekli de önem taşımaktadır. Dolayısıyla ölçme sonucunda bu değerlendirmeleri yapmaya, bir yargıya varmaya ve bu yargıya varmayı sağlayacak bir ölçüte ihtiyaç duyulmaktadır.

Ölçme ve değerlendirme kavramları çoğu durumda birbirinin yerine de kullanılan kavramlar olmakla birlikte "değerlendirme" daha geniş bir kavramdır. Özellikle öğretim sürecini esas alan yaklaşımlarda değerlendirme kavramı bu genişliği nedeniyle daha çok kullanılmaktadır. Adıgüzel (2013) yaratıcı drama süreçlerinde değerlendirmeyi, öğrenilenlerin kazanıma dönüşüp dönüşmediği ve bu durumun gelecek yaşantılara etkisinin olup olmayacağı, tüm yaratıcı drama yaşantı ve süreçlerinin nasıl algılandığı, nasıl anlaşıldığına yönelik duygu ve düşüncelerin paylaşılması olarak tanımlanmaktadır. Bu aşama tartışma ve görüş alışverişi biçiminde sözel olabileceği gibi rol içinde ve rol dışında yazma çalışmaları biçiminde de gerçekleştirilebilmektedir. Yöntem olarak yaratıcı dramada diğer ölçme ve değerlendirme araç ve yöntemleri de kullanılabilir.

Amerikan Eğitim İstatistikleri Ulusal Merkezi (NAEP, 1998) tarafından yayınlanmış olan sanat eğitiminin değerlendirilmesi ile ilgili incelemede özellikle drama alanında sürecin yaratma, icra ve yansıtma boyutlarına değinilmiştir. Bu boyutların her birisinin değerlendirilmesi gerektiği ve bu noktada farklı ölçme ve değerlendirme yöntem ve tekniklerine başvurulması gerektiği ifade edilmiştir. İster yöntem olarak, ister disiplin olarak kullanılıyor olsun, yaratıcı drama süreçlerinde de atölye veya oturum olarak ifade edilen eğitsel yapılar bulunmaktadır. Bu yapılar katılımcıların yaşantılarından (hazırbulunuşluklarından) hareketle, belirli kazanımların, belirli etkinliklerle gerçekleştirildiği ve sonucunda kazanımın gerçekleşme durumunun kontrol edildiği bir özelliktedir. Kısacası yaratıcı drama atölyesi, girdileri, süreci ve çıktıları olan kendi başına bir eğitim öğretim sürecini temsil etmektedir.

Bütün eğitim-öğretim süreçlerinde olduğu gibi yaratıcı drama sürecinde de değerlendirme, çalışma öncesinde, çalışma anında, çalışma sonunda ve/veya sonrasında yapılabilir. Yaratıcı dramanın aşamalarının her birinin ya da birkaçının ardından tartışmanın açılması, eleştiri-özeleştiri, soru-cevap etkileşiminin başlaması değerlendirmenin de somut başlangıcı olarak kabul edilebilir (Adıgüzel, 2013). 
Okvuran (2003), drama öğretmeninin yeterliliklerini ele aldığı çalışmasında; dramanın bazı özelliklerini; "Drama bir süreçtir. Başlangıçla şimdi arasında bir fark vardır. Drama, dramatik yaşantılara dayalıdır. Dramada gerçekle oyun iç içedir. Drama eğitimi bütünleştirir. Drama bilgiyi yaşantıya dönüştürür." biçiminde sıralamaktadır.

Aynı çalışmasında Okvuran (2003), MEB'in öğretmen yeterlilikleri çalışmasını da ele almıştır. Buna göre yeterlilik kavramı bir işi veya görevi yapabilme gücü olarak tanımlanmaktadır. Yeterlilik ölçülebilir, gözlenebilir olmalı ve bir süreç sonunda hizmet, ürün, nitelik ya da uygunluk olarak ortaya çıkmalıdır. Adı geçen çalışmada öğretmen yeterlilikleri arasında ele alınan "Öğretmenin eğitme-öğretme yeterlilikleri” ise öğrenciyi tanıma, öğretimi planlama (öğretimin amacını, içeriğini, etkililiğini, ortamını, materyali, planı yapma ve öğretim yöntemlerini kullanma), materyal geliştirme, öğretimi yapma (öğrencinin ilgi ve dikkatini çekme, önceden öğrenilenlerle bağlantı kurma, öğrencileri öğretim etkinliğine katma, dersi özetleme, değerlendirme, öğrencinin eksik ve yanlışlarını giderme, öğretim yöntemlerini kullanma vb.), öğretimi yönetme, başarıyı ölçme ve değerlendirme, rehberlik yapma gibi yeterlilikler yer almaktadır. Bu durum Karadăg, Korkmaz ve Yüksel (2008) tarafından şu şekilde ifade edilmektedir:

"Drama ile ilgili hangi tanımı benimsersek benimseyelim drama dersinden söz edebilmemiz için katılımcılara (öğrenci/öğretmen), belirli bir mekâna (sınıf), belirli bir içeriğe (ders/konu içeriği) ve bu sürecin devamını sağlayan drama liderine (öğretmen) ihtiyaç vardır. Bu katılımcılardan olan öğretmen drama etkinliklerinin önemli bir ögesidir. Öğretmen süreç içerisinde, hedefleri belirleyen, kazandırılacak davranışları planlayan, bunun için kullanılacak teknikleri seçen, bu süreçte yararlanılacak materyalleri sağlayan ve nihayet kazanımlar ile öğrenme sürecinin nasıl değerlendirileceğine karar veren kişidir."

Okvuran (2003) alanyazında belirtilen drama öğretmeninin becerilerine ek olarak ölçme ve değerlendirme konu alanı ile doğrudan bağlantılı yeterlilikleri; diğer derslerle bağlantı kurabilme becerisi, drama dersini planlayabilme becerisi, drama öğretim yöntemleri bilgisi, drama programı yapabilme becerisi, öğrencilerden kendi performansı ile ilgili geri bildirim alma, öğrencilerin drama performansını değerlendirme, geri bildirim verme, dramada sonuca da sürece de önem verebilme, bireysel farkl11ıkları dikkate alabilme, dramada yıllık/ünite/günlük planları hazırlayabilme, bütün öğrencilerine eşit davranabilme, biçiminde vurgulamaktadır.

Benzer olarak Adıgüzel (2013), yaratıcı drama, ölçme ve değerlendirme, lider arasındaki ilişkiyi "Yaratıcı drama atölyelerinde diğer tüm derslerde kullanılacak ölçme ve değerlendirme teknikleri kullanılabilir. Yaratıcı drama liderinin alternatif ölçme ve değerlendirme tekniklerini bilmeleri ve atölyelerinde etkin bir biçimde kullanabilecek yeterlilikte olmaları beklenmektedir." biçiminde ifade etmiştir.

Yaratıcı drama süreçlerinde ölçme ve değerlendirmenin önemi üzerine ne tür çalışmalar yapıldığını belirlemek üzere alanyazın taraması yapılmıştır. Bu doğrultuda ilk olarak Yaratıcı Drama Bibliyografyası (YDB), Yaratıcı Drama Dergisi (YDD) ve yaratıcı drama liderliği sertifika programı çerçevesinde yürütülen proje çalışmaları incelenmiştir. İkinci olarak ise Yükseköğrenim Kurulu(YÖK) tez veri tabanı incelenmiştir. Yaratıcı drama bibliyografyası 2014 yılına kadar olan tüm alan yazını içermektedir. Bu nedenle yaratıcı drama dergisi, YÖK Tez Merkezi ve Liderlik Projeleri için 2014 yılından sonraki dönemi kapsayacak tarama gerçekleştirilmiş öncesine ait veriler bibliyografyadan 
alınmıştır. Araştırmalarda bulunabilecek alan yazının çok sınırlı olacağı beklentisinden hareketle olabildiğince geniş bir arama yapabilmek için konu alanı için en temel anahtar kelimelerden ikisi olan "ölçme/ölçek" ve "değerlendirme" kavramları kullanılmıştır. Araştırma sonucunda; adında, konusunda, anahtar kelimelerinde belirlenen anahtar kelimelere rastlanan çalışmaların sayısı Tablo 1 'de sunulmuştur.

Tablo 1. Başlığında "yaratıcı drama”, ölçme/ölçek" ve "değerlendirme” geçen tezlerin dağılımı

\begin{tabular}{|c|c|c|c|c|c|c|c|}
\hline & \multirow{3}{*}{$\begin{array}{l}\text { Toplam } \\
\text { Kaynak } \\
\text { Sayısı }\end{array}$} & \multicolumn{6}{|c|}{ Anahtar Kelimeler } \\
\hline & & \multicolumn{2}{|c|}{ Yaratıcı Drama } & \multicolumn{2}{|c|}{ Ölçme/Ölçek } & \multicolumn{2}{|c|}{ Değerlendirme } \\
\hline & & $f$ & Yüzde & $f$ & Yüzde & $f$ & Yüzde \\
\hline${\text { YD Bibliyografyas }{ }^{1}}^{1}$ & 1270 & 737 & $58 \%$ & 7 & $1 \%$ & 29 & $2,28 \%$ \\
\hline YD Dergisi² & 28 & 14 & $50,00 \%$ & 1 & $3,57 \%$ & 1 & $3,57 \%$ \\
\hline YD Liderlik Projeleri ${ }^{3}$ & 68 & 0 & $0 \%$ & 0 & $0 \%$ & 0 & $0 \%$ \\
\hline YÖK tez merkezi ${ }^{4}$ & 38 & 38 & $100 \%$ & 0 & $0 \%$ & 1 & $0,04 \%$ \\
\hline Toplam & 1404 & 789 & $56 \%$ & 8 & $1 \%$ & 31 & $2 \%$ \\
\hline \multicolumn{8}{|c|}{ I: Adıgüzel, Ö., Metinnam İ. ve Özen Z. (2014). Yaratıcı Drama Bibliyografyası. } \\
\hline $\begin{array}{l}\text { 2: 15-18. Sayllar arasinda yay } \\
\text { 3: } 2014 \text { yılından sonra yapılar }\end{array}$ & $\begin{array}{l}\text { ış makaleler } \\
\text { listesi esas a }\end{array}$ & $\begin{array}{l}\text { alınmis } \\
\text { sttr. }\end{array}$ & & & & & \\
\hline
\end{tabular}

Tablo 1'e göre, 2016 yılı itibariyle toplam 1404 adet araştırma ve kitap içerisinde sadece 39 adet ölçme ve değerlendirmeyi konu edinen çalışma yer almaktadır. Bunun bütün çalışmalara oranı \%3'tür ( $\mathrm{f}=39$ ). Belirlenen anahtar kelimelere uygun olarak yapılan tarama sonunda son derece sinırlı sayıda çalışmaya ulaşılmaktadır. Bu durum aynı zamanda yaratıcı dramanın disiplin boyutunda; ölçme ve değerlendirme konusunda yürütülen araştırmaların da sınırlı sayıda olduğunu göstermektedir. $\mathrm{Bu}$ sayının nicelik olarak azlığı bir kenara bırakılarak ve anahtar kelime yerine, ölçme ve değerlendirme kavramlarının herhangi bir araştırmada içerik bağlamında ele alınması incelendiğinde, proje ve tez bazında inceleme sonucu Tablo 2'de sunulmuştur.

Tablo 2. Proje Tarama Bulguları (yıllara göre siralı) ${ }^{l}$

\begin{tabular}{lllll}
\hline Sıra & Tür & Çalışmanın Adı & Yazan & Yıl \\
\hline 1 & YD Liderlik & Müze Eğitim Bilimi (Pedagojisi) ve Türkiye’deki & Nami Eren Beştepe & 1995 \\
& Projesi & $\begin{array}{l}\text { Arkeoloji Müzelerinin Eğitim Ortamı Olarak } \\
\text { Etkililiğinin Değerlendirilmesi }\end{array}$ & & \\
\hline 2 & YD Liderlik & Eğitim Programının Öğeleri ve Yaratıcı Drama & Necla Koksal & 2006 \\
& Projesi* & & & \\
\hline 3 & YD Liderlik & İlköğretim Sanat Etkinlikleri Dersinde Yaratıcı & Murtaza Aykaç & 2007 \\
& Projesi* & $\begin{array}{l}\text { Drama Yönteminin Öğrenci Memnuniyeti } \\
\text { Açısından Değerlendirilmesi }\end{array}$ & & \\
& & & & \\
\hline
\end{tabular}


Yaratıcı Drama Lider ve Lider Adaylarının Ölçme ve Değerlendirme Konularındaki Profilleri ve Görüşleri

\begin{tabular}{lllll}
\hline Sıra & Tür & Çalışmanın Adı & Yazan & Yıl \\
\hline 4 & YD Liderlik & Yaratıcı Drama İle Ölçme ve Değerlendirmeye & İlke Önal Çalışkan & 2008 \\
& Projesi & Bakış & & \\
\hline 5 & YD Liderlik & Düşünme Eğitimi Dersinin Yaratııı Drama & Neşat & 2010 \\
& Projesi & $\begin{array}{l}\text { Yöntemi İle İşlenmesinin Öğrencilerin Başarısı } \\
\text { ve Memnuniyeti Açısından Etkililiğinin }\end{array}$ & Yadigaroğulları & \\
& & Değerlendirilmesi & & \\
& & İlköğretim öğrencilerine halk dansları & Tanju Kanbertay & 2010 \\
& YÖK & öğretiminde yaratıcı drama yöntemi & Bozkurt & \\
& Y.lisans tezi & kullanılmasının değerlendirilmesi & & 2012 \\
\hline 7 & YD Liderlik & Yaratıcı Drama Temelli Çocuk Hakları Eğitimi & Serkan Keleşoğlu & \\
& Projesi & Programının Değerlendirilmesi & & \\
\hline
\end{tabular}

*:Aynı zamanda makale haline getirilerek Yaratıcı Drama Dergisi’nde yayınlanmıştır.

${ }^{1}$ : 2014 y1lında düzenlenmiş proje listesi esas alınmıştır.

Yaratıcı drama alanında yürütülen pek çok çalışmada, yaratıcı drama atölye planlarının içerisinde veya proje alt başlığının gereği olarak, ölçme ve değerlendirme unsuları kullanılmaktadır. Ancak ölçme ve değerlendirmenin yaratıcı dramanın disiplin boyutu içerisindeki yeri ve önemine ilişkin sonuçları ele aldığında, bulunan araştırma sonuçlarından sadece ikisinin ilişkili olduğu görülmektedir. Bunlar; İlke Önal Çalışkan'ın "Yaratıcı Drama ile Ölçme ve Değerlendirmeye Bakış" çalışması ile Necla Köksal'ın “Eğitim Programının Öğeleri ve Yaratıcı Drama” çalışmasıdır.

Sonuç olarak; yaratıcı drama bir öğretim yöntemi olmanın yanı sıra aynı zamanda girdileri, süreci ve çıktıları olan atölyelerinin yapısı gereği, küçük ölçekli bir eğitim sistemidir. Bu çerçevede ölçme ve değerlendirme sürecin ayrılmaz, gerekli ve önemli bir parçasıdır. Wiggins ve Mctighe "bir şeyi ölçemiyorsanız, o şey yoktur” demiştir (Aktaran, Adıgüzel, 2013). Bu bağlamda yaratıcı drama alanını değerlendirdiğimizde, ölçme tekniklerinin mutlaka bilinmesi ve yaratıcı drama lideri tarafından kullanılması gerekliliği ortaya çıkmaktadır. Çünkü yaratıcı dramada var olan atölye/oturum/süreç kazanımları/hedefleri/amaçları yanı sıra katılımcılara ilişkin ölçülebilecek/değerlendirilebilecek ve ortaya çıkarılacak çok şey bulunmaktadır. Öğrenmelerin gerçekleşme durumunun tespiti, kalıcılığının belirlenmesi ve gerekli durumlarda sürecin yeniden yapılandırılması için veri sağlanması bakımından her yaratıcı drama atölyesi içinde ölçme ve değerlendirmenin yer alması gerekmektedir.

\section{Araştırmanın Önemi}

Yaratıcı drama süreçlerinde ölçme ve değerlendirmenin kullanımı ve etkililiği konusunda alan yazında yeterli araştırma bulunmamaktadır. Benzer olarak ölçme ve değerlendirmenin öğretiminde de yaratıcı dramanın yöntem olarak kullanılmasına ilişkin araştırma bulgusuna rastlanamamaktadır. Diğer yandan alan yazında ölçme değerlendirme yaratıcı drama lider ve adaylarının sahip olması gereken yeterlilikler arasında ifade edilmektedir. Buna karşın yaratıcı drama lider ve adaylarının ölçme değerlendirme konusundaki yeterlilik düzeylerine veya bu konudaki farkındalıklarına ilişkin de araştırma bulgusuna rastlanamamaktadır. Dolayısıyla yaratıcı drama ile yakından ilgilenen ve uygulayıcısı olan kişilerin ölçme ve değerlendirme konusundaki yeterliliklerinin geliştirilebilmesi için öncelikle bu kişilerin ölçme ve değerlendirme konusundaki profillerinin ve görüşlerinin belirlenmesi önem taşımaktadır. Araştırmadan elde edilecek bulguların lider yetiştirme programlarını bu konuda geliştireceği düşünülmektedir. 


\section{Araştırmanın Amacı}

$\mathrm{Bu}$ araştırmanın amacı; yaratıcı drama lider ve lider adaylarının, yaratıcı drama süreçlerinde kullanılan/kullanılabilecek ölçme ve değerlendirme konularındaki profillerini ve görüşlerini belirlemektir. Bu amaca yönelik olarak şu üç soruya yanıt aranmıştır.

1. Yaratıcı drama lider ve lider adaylarının ölçme ve değerlendirme konusundaki eğitim düzeyleri nasıldır?

2. Yaratıcı drama lider ve lider adayları ölçme ve değerlendirme yöntem ve tekniklerini nasil kullanmaktadir?

3. Yaratıcı drama lider ve lider adaylarının ölçme ve değerlendirme konularında kendilerini yeterli görmekte midir?

\section{Yöntem}

\section{Araştırmanın Modeli}

Araştırma modeli itibariyle tarama modelinde bir çalışmadır. Tarama modelleri, geçmişte ya da halen var olan bir durumu var olduğu şekliyle betimlemeyi amaçlayan araştırma yaklaşımlarıdır. Araştırmaya konu olan olay, birey ya da nesne kendi koşulları içinde olduğu gibi tanımlanmaya çalış1ır. Herhangi bir şekilde değişkenleri değiştirme, etkileme söz konusu değildir. Tarama araştırmalarıyla yalnızca "Nedir?" sorusuna cevap aranmaz aynı zamanda geçmiş olaylarla ilgili değişkenler arasında ilişki kurma (korelasyon) ve bu ilişkiler arasında olası neden/sonuç değişkenkenleri hakkında yargılarda bulunabilme amacıyla (karşılaştırmalı araştırmalar) kanıtların toplanması ve değerlendirilmesi de söz konusudur. Böylelikle tarama modeli doğasında, hem nitel araştırma tasarımlarını hem de nicel araştırma tasarımlarını bir arada barındırır (Karasar, 2012). Araştırmada katılımcı görüşlerine doğrudan ulaşmak ve alıntı yapabilmek amacıyla geliştirilen anketten yararlanılmıştır.

\section{Çalışma Grubu}

$\mathrm{Bu}$ çalışmada amaçlı örnekleme yöntemlerinden kolay ulaş1labilir örneklemeden yararlanılmıştır. Bu örneklemede amaç; araştırmaya esas oluşturacak verilerin sağlanacağı bireyler grubu içerisinden, zamansal ve mekânsal olarak görece kolay ulaşılabilir birimlerin seçilmesiyle örneklemin oluşturulmasıdır. En kısa zamanda ve en az maliyetle bilgi üretilmesine ihtiyaç duyulduğu durumlarda kullanılan bir örnekleme yöntemidir. (Özmen, 2006)

$\mathrm{Bu}$ doğrultuda çalışmaya Çağdaş Drama Derneğinin, İstanbul, Ankara, İzmir ve Eskişehir şubelerinden 5. ve 6. Aşamada eğitim alan yaratıcı drama lider adayları ile yaratıcı drama lideri toplam 114 kişi katılmıştır. Katılımcıların genel özellikleri aşağıdaki gibidir.

Tablo 3. Yaratıcı drama ĕ̌itmenliği programındaki seviye dă̆llımı

\begin{tabular}{llll}
\hline & & & $\begin{array}{l}\text { Yığmalı } \\
\text { Yüzde }\end{array}$ \\
\hline 5. Aşama & 32 & 28,1 & 28,1 \\
\hline 6. Aşama & 61 & 53,5 & 81,6 \\
\hline Lider & 21 & 18,4 & 100,0 \\
\hline Toplam & 114 & 100,0 & \\
\hline
\end{tabular}


Katılımcıların yaklaşık yarısı “6. Aşama” düzeyindedir. Elde edilen verilerin dağılımı ise her üç aşama için de verilerden hareketle yorumların yapılabilmesini sağlayacak sayıdadır.

Tablo 4. Anket yanıtlayıcılarının sektörlere göre dă̆llımı

\begin{tabular}{llll}
\hline & & & $\begin{array}{l}\text { Yığmalı } \\
\text { Yüzde }\end{array}$ \\
\hline Eğitim & 87 & 76,3 & 76,3 \\
\hline Finans & 3 & 2,6 & 78,9 \\
\hline Ticaret & 1 &, 9 & 79,8 \\
\hline Bilişim & 1 &, 9 & 80,7 \\
\hline Mühendislik & 1 &, 9 & 81,6 \\
\hline Sağllk & 4 & 3,5 & 85,1 \\
\hline Hizmet sektörü & 5 & 4,4 & 89,5 \\
\hline Diğer & 3 & 2,6 & 92,1 \\
\hline Sanat & 9 & 7,9 & 100,0 \\
\hline Toplam & 114 & 100,0 & \\
\hline
\end{tabular}

Katılımcıların önemli bir kısmı "Eğitim" sektöründendir. $(\% 76,3) \mathrm{Bu}$ durum ölçme ve değerlendirme konusunda belirli bir alt yapıya sahip olmaları gerektiği ile ilgili fikir vermektedir.

Tablo 5. Ĕ̈itim sektöründeki iş/uzmanlık dă̆ılımı

\begin{tabular}{llll}
\hline & & & Yı̆̆malı \\
& $f$ & Yüzde & Yüzde \\
\hline Anaokulu öğretmeni & 12 & 13,8 & 13,8 \\
\hline Sinıf öğretmeni & 12 & 13,8 & 27,6 \\
\hline Yaratıcı Drama öğretmeni & 9 & 10,3 & 37,9 \\
\hline Branş öğretmeni & 29 & 33,3 & 71,3 \\
\hline Rehber öğretmen & 5 & 5,7 & 77,0 \\
\hline Akademisyen & 11 & 12,6 & 89,7 \\
\hline Uzman (EPÖ, EĞİTEK, EÖD)* & 2 & 2,3 & 92,0 \\
\hline Öğrenci & 3 & 3,4 & 95,4 \\
\hline Diğer & 2 & 2,3 & 97,7 \\
\hline Yetişkin eğitimi & 2 & 2,3 & 100,0 \\
\hline Toplam & 87 & 100,0 & \\
\hline
\end{tabular}

*EPÖ: eğitim programları ve öğretim, EĞİTEK: eğitim teknolojileri, EÖD: eğitimde ölçme ve değerlendirme

Katılımcılar üçte biri branş öğretmenlerinden $(\% 33,3)$ oluşmaktadır. Buradan hareketle ölçme ve değerlendirmeyi aktif olarak kullanan kişiler oldukları da söylenebilir. 


\section{Veri Toplama Aracı}

Araştırmanın gerekçesi doğrultusunda yaratıcı drama lider ve lider adaylarının;

- ölçme ve değerlendirme konusunda eğitim durumlarına

- $\quad$ ölçme ve değerlendirme yöntem ve teknikleri konusunda görüşlerine

- $\quad$ ölçme ve değerlendirme yöntem ve tekniklerinden yararlanma sıklık ve şekillerine

yönelik durum belirlemesi yapmak amacıyla araştırmacı tarafından "Yaratıcı Drama Lider ve Lider Adaylarının Ölçme ve Değerlendirme Konusundaki Görüşlerini Belirleme Anketi” geliştirilmiştir. Anket geliştirme sürecinde hazırlanmış olan taslak 18 soru önce bir ölçme değerlendirme uzmanı tarafindan incelenerek, ifadelerin kurulumu ve soruluş sırası ile ilgili görüş alınmıştır. Ardından düzenlenen sorular yaratıcı drama lider adayından oluşan üç kişilik bir gruba yöneltilmiş ve soruların anlaşılırlığı, yanıtlanabilirliği, binişikliği ile ilgili görüşler alınmıştır. Alınan geri bildirim neticesinde 12 sorudan oluşturulan nihai anket iki ayrı ölçme değerlendirme uzmanı tarafından geçerlik, güvenirlik ve kullanışlılık açısından yeniden değerlendirilmiş ve ankete son hali verilmiştir. Anket soruları ekte yer almaktadır.

\section{Verilerin Toplanması ve Analizi}

Çalışmada araştırmacı; araştırma sürecinin tasarlanması, yürütülmesi ve sonlandırılması; uygulama sürecinin planlanması, uygulama ortamının oluşturulması ve yürütülmesi; gerekli analizlerin yapılması ve bulgular ile sonuçların raporlaştırılmasına yönelik rol ve sorumluluklar üstlenmiştir.

Geliştirilen anket çevrimiçi olarak uygulanmak üzere lider adayları ile yaratıcı drama liderlerine elektronik posta yoluyla gönderilmiştir. Anket soruları uygulama kolaylığı sağlaması bakımından Google form yardımıyla çevrimiçi olarak uygulamaya hazırlanmıştır. Anketlerin ulaştırılmasında yardım almak amacıyla Çağdaş Drama Derneği’nin İstanbul, Ankara, İzmir ve Eskişehir şube yönetimlerine dilekçe ile başvurulmuştur. Geliştirilen anket sağlanan duyuru desteği ile 45 günlük süre içerisinde 114 katılımcıya uygulanmıştır.

Elde edilen anket sonuçları SPSS 19 paket programı kullanılarak analiz edilmiştir. Analizlerde frekans ve çapraz tablolardan yararlanılmıştır.

\section{Bulgular}

Bu bölümde çalışma kapsamında ele alınan yaratıcı drama lider ve lider adaylarının ölçme ve değerlendirme yöntem ve teknikleri konusunda eğitim durumları, bu yöntem ve tekniklerden yararlanma şekilleri, bunlara ilişkin görüşleri ile ilgili bulgulara yer verilmiştir.

\section{Yaratıcı drama lider ve lider adaylarının ölçme ve değerlendirme konusundaki eğitim düzeyleri nasıldır?}

Bu soru için katılımcılara daha önce ölçme ve değerlendirme konusunda ve nitel veya nicel araştırma yöntemleri konusunda eğitim alıp almadıkları sorulmuştur. Verilen yanıtların dağılımı Tablo 6'daki gibidir. 
Tablo 6. YD eğitmenliği programındaki seviyesine göre YD programı dışında ölçme ve değerlendirme ĕgitimi alma durumlar

Daha önce YD (Yaratıcı Drama) programı dışında ölçme değerlendirme

konusunda eğitim aldınız mı?

\begin{tabular}{lllllll}
\hline & Hayır & \multicolumn{3}{c}{ Evet } & \multicolumn{3}{c}{ Toplam } \\
\cline { 2 - 7 } & $f$ & Yüzde & $f$ & Yüzde & $f$ & Yüzde \\
\hline 5. Aşama & 20 & $62,50 \%$ & 12 & $37,50 \%$ & 32 & $100,0 \%$ \\
\hline 6. Aşama & 28 & $45,90 \%$ & 33 & $54,10 \%$ & 61 & $100,0 \%$ \\
\hline Lider & 5 & $23,80 \%$ & 16 & $76,20 \%$ & 21 & $100,0 \%$ \\
\hline Toplam & 53 & $46,50 \%$ & 61 & $53,50 \%$ & 114 & $100,0 \%$ \\
\hline
\end{tabular}

Anket yanıtlayıcılarının \% 53,5'u yaratıcı drama programı dışında daha önce ölçme ve değerlendirme konusunda eğitim aldığını ifade etmektedir. Ancak \%46,5 ile önemli bir kısım bu konuda eğitim almadığını belirtmektedir. Bu durum bir öğretim sürecinin planlayıcısı, yürütücüsü ve değerlendiricisi olan lider/öğretmenden beklenen yeterlilikleri karşılamamaktadır.

Tablo 7. YD ě̆itmenliği programındaki seviyesine göre YD programı dışında nitel veya nicel araştırma yöntemleri ĕgitimi alma durumları

Daha önce YD programı dışında nitel veya nicel araştırma yöntemleri

konusunda eğitim aldınız mı?

\begin{tabular}{lllllll}
\hline & Hayır & \multicolumn{3}{c}{ Evet } & \multicolumn{3}{c}{ Toplam } \\
\cline { 2 - 7 } & $f$ & Yüzde & $f$ & Yüzde & $f$ & Yüzde \\
\hline 5. Aşama & 17 & $53,1 \%$ & 15 & $46,9 \%$ & 32 & $100,0 \%$ \\
\hline 6. Aşama & 35 & $57,4 \%$ & 26 & $42,6 \%$ & 61 & $100,0 \%$ \\
\hline Lider & 5 & $23,8 \%$ & 16 & $76,20 \%$ & 21 & $100,0 \%$ \\
\hline Toplam & 57 & $50,0 \%$ & 61 & $50,0 \%$ & 114 & $100,0 \%$ \\
\hline
\end{tabular}

Tablo 6 ve 7 birlikte incelendiğinde katılımcıların önemli bir kısmının araştırma yöntemleri ve ölçme ve değerlendirme konularında eğitim almış oldukları görülmektedir. Bu durum katılımcıların büyük bir çoğunlukla "eğitim" sektöründen gelmiş olmalarının sonucu olabilir. Fakat yarı yarıya olan bu dağılım da yine belirlenmiş olan yeterliliklerin karşılanamadığını göstermektedir.

Diğer yandan yukarıda bahsedilen konulardaki yeterliliğin, yaratıcı drama süreçlerinden elde edilebileceği düşünülebilir. Ancak, bu konuda Hasırcı, Bulut ve Saban (2008) tarafından yapılan çalışmanın sonucunda yaratıcı dramanın lider ve lider adaylarının ölçme ve değerlendirme yeterliliklerini geliştirmeye katkı sağlamadığı ifade edilmiştir. Bu bakımdan yaratıcı drama programı dışında veya içinde ölçme ve değerlendirme eğitimi almış olmanın yeterliliği karşılayamayacağ ifade edilebilir.

\section{Yaratıcı drama lider ve lider adayları ölçme ve değerlendirme yöntem ve teknik- lerini nasıl kullanmaktadır?}

Bu bölümde katılımcılara yaratıcı drama atölyelerinde ölçme ve değerlendirme için ne kadar süre ayırdıkları, sıklıkla hangi tür ölçme ve değerlendirmeden yararlandıkları, sıklıkla kullandıkları 
ölçme ve değerlendirme formatı, yapılan ölçme ve değerlendirmeler ile ilgili kayıt tutma ve geri bildirim verme sıklıkları ile ilgili bulgulara yer verilmiştir.

Tablo 8. YD atölyelerinde (3 saatlik bir oturumda) ölçme ve değerlendirme uygulamaları için ayrılan toplam süre dă̆ılımı

\begin{tabular}{llll}
\hline & & & $\begin{array}{l}\text { Yı̆ğmalı } \\
\text { Yüzde }\end{array}$ \\
\hline $10 \mathrm{dk}$ ve daha az & 9 & 7,9 & 7,9 \\
\hline 11 - 20 dk & 53 & 46,5 & 54,4 \\
\hline $21 \mathrm{dk}$ ve daha fazla & 52 & 45,6 & 100,0 \\
\hline Toplam & 114 & 100,0 & \\
\hline
\end{tabular}

Bu tabloya göre katılımcılar YD atölyelerinde uygun bir süreyi ölçme ve değerlendirme için ayırıyor görünmektedir. Alanyazında öğretim sürecinde ölçme değerlendirme için ayrılan süreye ilişkin belirgin bir öneri bulunmamakla birlikte örgün öğretimde 40 dakikalık bir sınıf içi uygulama için 5 dakikalık bir süre uygun görülebilir. Buradan hareketle 180 dakikalık bir yaratıcı drama atölyesi için 20 dakikalık bir sürenin ölçme ve değerlendirme için ayrılmasının uygun olabileceği düşünülebilir. Ayrılan süre etkinliğin ve kazanımın niteliği ile doğru orantılı olarak değişiklik gösterebilir. Buna karşın \%7,9'luk bir grup ölçme ve değerlendirme için 10 dakikadan az bir zaman ayırmaktadır. Bu sürenin ortalama olarak ifade edildiğinden az olduğu söylenebilir.

Tablo 9. YD atölyelerini planlarken (3 saatlik bir oturumda) yer verilen değerlendirmelerin dă̆ılımı

\begin{tabular}{llll}
\hline & $f$ & Yüzde & $\begin{array}{l}\text { Yığmalı } \\
\text { Yüzde }\end{array}$ \\
\hline Sadece genel (sonuç) değerlendirme & 1 & 9 &, 9 \\
\hline $\begin{array}{l}\text { Ara ve genel değerlendirme ama ara değerlendirme } \\
\text { ağırlıklı }\end{array}$ & 6 & 5,3 & 6,1 \\
\hline $\begin{array}{l}\text { Ara ve genel değerlendirme ama genel } \\
\text { değerlendirme ağırlıklı }\end{array}$ & 74 & 64,9 & 71,1 \\
\hline Ara ve genel değerlendirme dengeli & 32 & 28,1 & 99,1 \\
\hline Hiçbiri & 1 &, 9 & 100,0 \\
\hline Toplam & 114 & 100,0 & \\
\hline
\end{tabular}

Elde edilen verilere göre katılımcıların büyük çoğunluğu $(\% 64,9)$ atölyelerinde hem ara hem de genel (sonuç) değerlendirmeye yer vermekte, ancak genel değerlendirme ağırlıklı olmaktadır. Buradan hareketle atölye planlarında kazanıma ulaşma noktasında yaşanan sürecin değerlendirilerek, gerekli durumda anlık plan düzenleme ve geliştirmeye daha az başvurulduğu anlaşılmaktadır. Ölçme ve değerlendirmenin hem erişi hem de sürece yönelik çıktılar sunabildiği ve sürece yönelik çıktıların sistemin kontrolü ve yeniden düzenlemesi açısından etkili bir fonksiyon üstlendiği düşünüldüğünde, genel değerlendirmenin bu denli ağırlıklı kullanılıyor olmasının süreçsel bir yaklaşımı olan dramanın etkililiği açısından sakıncalı olabileceği söylenebilir. 
Tablo 10. YD atölyeleri içerisinde (3 saatlik bir oturumda) yer verilen değerlendirmelerin formatı

\begin{tabular}{|c|c|c|c|}
\hline & $f$ & Yüzde & $\begin{array}{l}\text { Yığmalı } \\
\text { Yüzde }\end{array}$ \\
\hline Sadece sözel ölçme değerlendirme & 24 & 21,1 & 21,1 \\
\hline Her ikisi de ama sözel ölçme değerlendirme ağırlıklı & 65 & 57,0 & 78,1 \\
\hline Her ikisi de ama sayısal ölçme değerlendirme ağırlıklı & 6 & 5,3 & 83,3 \\
\hline Her ikisi dengeli & 18 & 15,8 & 99,1 \\
\hline Hiçbiri & 1 & ,9 & 100,0 \\
\hline Toplam & 114 & 100,0 & \\
\hline
\end{tabular}

Tablo 8 incelendiğinde YD lider ve adaylarının ağırlıklı olarak sadece sözel ya da sözel ağırlıklı olacak biçimde $(\% 78,1)$ bir değerlendirme formatını tercih ettikleri görülmektedir. Bu durum verilerin nesnelliğinin sağlanması ve takibinin yapılabilmesi açısından olumsuz etkiler yaratabilecek bir durum olarak karşımıza çıkmaktadır.

Tablo 11. YD ĕgitmenliği programındaki seviyesine göre "YD atölyelerinde yaptığını ölçme ve değerlendirme sonuçları için bir izleme/takip kaydı tutuyor musunuz?" sorusuna verilen yanıtların dă̆ılımı

\begin{tabular}{lcccccccccc}
\hline & \multicolumn{2}{l}{ Hiçbir Zaman } & \multicolumn{2}{l}{ Bazen } & \multicolumn{2}{l}{ Çogunlukla } & \multicolumn{2}{l}{ Her Zaman } & \multicolumn{2}{c}{ Toplam } \\
\cline { 2 - 11 } & $f$ & Yüzde & $f$ & Yüzde & $f$ & Yüzde & $f$ & Yüzde & $f$ & Yüzde \\
\hline 5. Aşama & 5 & $15,60 \%$ & 10 & $31,30 \%$ & 11 & $34,40 \%$ & 6 & $18,80 \%$ & 32 & $100,00 \%$ \\
\hline 6. Aşama & 9 & $14,80 \%$ & 19 & $31,10 \%$ & 21 & $34,40 \%$ & 12 & $19,70 \%$ & 61 & $100,00 \%$ \\
\hline Lider & 2 & $9,50 \%$ & 8 & $38,10 \%$ & 8 & $38,10 \%$ & 3 & $14,30 \%$ & 21 & $100,00 \%$ \\
\hline Toplam & 16 & $14,00 \%$ & 37 & $32,50 \%$ & 40 & $35,10 \%$ & 21 & $18,40 \%$ & 114 & $100,00 \%$ \\
\hline
\end{tabular}

Katılımcılar atölyelerinde ölçme ve değerlendirme için \%92,1 oranında 10 dakikanın üzerinde zaman ayırıyor oldukları halde bu sürece ilişkin olarak ancak \%46,5 kadarı sonuçlara ait bir kayıt tutmaktadır. Bu oran hem programın değerlendirilmesi ve geliştirilebilmesi hem de katılımcılara gerekli geri bildirimin sağlanması açılarından yetersiz görünmektedir. Diğer yandan ölçme ve değerlendirme sonuçlarının yeniden kullanması ve/veya işlenmesi boyutunda da önemli bir veri kaybına işaret etmektedir.

Ayrıca bu tablodan elde edilen veri Tablo 8'den elde edilmiş olan \%78,1'lik sadece sözel veya sözel ağırlıklı değerlendirme formatının benimsendiği verisi ile birlikte ele alındığında YD atölyelerinde kazanıma ulaşılıp ulaşılamadığının nesnel bir takibinin yapılamadığını düşündürmektedir. 
Tablo 12. YD ĕgitmenliği programındaki seviyesine göre "YD atölyelerinde yaptığınız ölçme ve değerlendirmelerin sonucunda katılımcılara ne sıklıkla geri bildirim verirsiniz?" sorusuna verilen yanitların dağılımı

\begin{tabular}{lcccccccccc}
\hline & \multicolumn{2}{l}{ Hiçbir Zaman } & \multicolumn{2}{l}{ Bazen } & \multicolumn{2}{c}{ Çoğunlukla } & \multicolumn{2}{c}{ Her Zaman } & \multicolumn{2}{c}{ Toplam } \\
\cline { 2 - 11 } & $f$ & Yüzde & $f$ & Yüzde & $f$ & Yüzde & $f$ & Yüzde & $f$ & Yüzde \\
\hline 5. Aşama & 2 & $6,3 \%$ & 6 & $18,8 \%$ & 14 & $43,8 \%$ & 10 & $31,3 \%$ & 32 & $100,00 \%$ \\
\hline 6. Aşama & 4 & $6,6 \%$ & 18 & $29,5 \%$ & 25 & $41,0 \%$ & 14 & $23,0 \%$ & 61 & $100,00 \%$ \\
\hline Lider & 1 & $4,8 \%$ & 8 & $23,8 \%$ & 11 & $52,4 \%$ & 4 & $19,0 \%$ & 21 & $100,00 \%$ \\
\hline Toplam & 7 & $6,1 \%$ & 29 & $25,4 \%$ & 50 & $43,9 \%$ & 28 & $24,6 \%$ & 114 & $100,00 \%$ \\
\hline
\end{tabular}

Katılımcıların bu soruya verdikleri yanıtlar Tablo 9 ile birlikte incelendiğinde geri bildirim konusunda \%31,5'luk (hiçbir zaman ve bazen toplamı) önemli bir kaybın bulunduğu görülmektedir. Bu sorunun ardında yatan nedenler arasında ölçme ve değerlendirme sonuçlarının herhangi bir kaydının tutulmaması olabileceği gibi farklı nedenler de sıralanabilir. Buna göre eğitim öğretim sürecinin olmazsa olmazlarından biri olan geribildirimin YD atölyelerinde yeterli düzeyde gerçekleştirilmediği ifade edilebilir.

\section{Yaratıcı drama lider ve lider adaylarının ölçme ve değerlendirme konularında kendilerini yeterli görmekte midir?}

Katılımcılara ölçme ve değerlendirme konularındaki yeterliliklerine ilişkin yanıtlar ise aşağıdaki gibi değişmektedir.

Tablo 13. "Bildiklerinizden/deneyimlerinizden hareketle aşağıdaki konular ile ilgili yetkinliklerinizi derecelendiriniz." maddesine verilen yanıtların dă̆ılımı.

\begin{tabular}{|c|c|c|c|c|c|c|c|c|c|c|}
\hline & \multicolumn{2}{|c|}{$\begin{array}{l}\text { 1. Yeterli } \\
\text { değilim }\end{array}$} & \multicolumn{2}{|l|}{2} & \multicolumn{2}{|l|}{3} & \multicolumn{2}{|l|}{4} & \multicolumn{2}{|c|}{$\begin{array}{l}\text { 5. Çok } \\
\text { yeterliyim }\end{array}$} \\
\hline & $f$ & $\%$ & $f$ & $\%$ & $f$ & $\%$ & $f$ & $\%$ & $f$ & $\%$ \\
\hline $\begin{array}{l}\text { Nitel araştırma } \\
\text { yöntemleri }\end{array}$ & 30 & $26,32 \%$ & 20 & $17,54 \%$ & 41 & $35,96 \%$ & 19 & $16,67 \%$ & 4 & $3,51 \%$ \\
\hline $\begin{array}{l}\text { Nicel araştırma } \\
\text { yöntemleri }\end{array}$ & 30 & $26,32 \%$ & 28 & $24,56 \%$ & 34 & $29,82 \%$ & 18 & $15,79 \%$ & 4 & $3,51 \%$ \\
\hline $\begin{array}{l}\text { Örnekleme } \\
\text { teknikleri }\end{array}$ & 30 & $26,32 \%$ & 22 & $19,30 \%$ & 32 & $28,07 \%$ & 25 & $21,93 \%$ & 5 & $4,39 \%$ \\
\hline $\begin{array}{l}\text { Araştırma } \\
\text { desenleri }\end{array}$ & 45 & $39,47 \%$ & 23 & $20,18 \%$ & 26 & $22,81 \%$ & 15 & $13,16 \%$ & 5 & $4,39 \%$ \\
\hline Ölçme & & & & & & & & & & \\
\hline $\begin{array}{l}\text { değerlendirme } \\
\text { araçları }\end{array}$ & 26 & $22,81 \%$ & 18 & $15,79 \%$ & 38 & $33,33 \%$ & 22 & $19,30 \%$ & 10 & $8,77 \%$ \\
\hline
\end{tabular}


Bu tabloda "3" orta düzey bir yetkinliği ifade etmektedir. Buna göre 1-2 ve 3 orta düzey ve altında olan bir yetkinlik algısına işaret etmektedir. Tablodaki veriler incelendiğinde; yanıtlayıcıların \%79,82'sinin nitel araştırma yöntemleri bakımından, \%80,70'inin nicel araştırma yöntemleri bakımından, \%73,68'inin örnekleme teknikleri bakımından, \%82,46'sının araştırma desenleri bakımından, \%71,93'ünün ise ölçme ve değerlendirme araçları bakımından orta düzey ve altında yeterliğe sahip gördüğü anlaşılmaktadır. Diğer yandan hemen hemen tüm konu başlıklarında yetkinliklerle ilgili önemli bir kayıp olduğu söylenebilir.

Katılımcılara yöneltilen ölçme ve değerlendirme yöntem ve teknikleri ile ilgili yetkinliklere ilişkin yanıtlar ise Tablo 14'deki gibi değişmektedir.

Tablo 14. "Bildiklerinizden/deneyimlerinizden hareketle, aşağıdaki ölçme ve değerlendirme yöntem ve teknikleri ile ilgili yetkinliklerinizi derecelendiriniz. " maddesine verilen yanıtların dă̆ılımı.

\begin{tabular}{|c|c|c|c|c|c|c|c|c|c|c|}
\hline & \multicolumn{2}{|c|}{$\begin{array}{l}\text { 1. Yeterli } \\
\text { değilim }\end{array}$} & \multicolumn{2}{|l|}{2} & \multicolumn{2}{|l|}{3} & \multicolumn{2}{|l|}{4} & \multicolumn{2}{|c|}{$\begin{array}{l}\text { 5. Çok } \\
\text { yeterliyim }\end{array}$} \\
\hline & $f$ & $\%$ & $f$ & $\%$ & $f$ & $\%$ & $f$ & $\%$ & $f$ & $\%$ \\
\hline Soru-Cevap & 6 & $5,26 \%$ & 7 & $6,14 \%$ & 26 & $22,81 \%$ & 49 & $42,98 \%$ & 26 & $22,81 \%$ \\
\hline $\begin{array}{l}\text { Boşluk tamamlama } \\
\text { soruları }\end{array}$ & 7 & $6,14 \%$ & 15 & $13,16 \%$ & 20 & $17,54 \%$ & 55 & $48,25 \%$ & 17 & $14,91 \%$ \\
\hline $\begin{array}{l}\text { Kisa veya uzun } \\
\text { cevaplı sorular }\end{array}$ & 5 & $4,39 \%$ & 14 & $12,28 \%$ & 25 & $21,93 \%$ & 51 & $44,74 \%$ & 19 & $16,67 \%$ \\
\hline $\begin{array}{l}\text { Çoktan seçmeli } \\
\text { sorular }\end{array}$ & 8 & $7,02 \%$ & 16 & $14,04 \%$ & 29 & $25,44 \%$ & 45 & $39,47 \%$ & 16 & $14,04 \%$ \\
\hline Doğru yanlış soruları & 8 & $7,02 \%$ & 14 & $12,28 \%$ & 21 & $18,42 \%$ & 50 & $43,86 \%$ & 21 & $18,42 \%$ \\
\hline Eşleştirme soruları & 8 & $7,02 \%$ & 13 & $11,40 \%$ & 26 & $22,81 \%$ & 46 & $40,35 \%$ & 21 & $18,42 \%$ \\
\hline $\begin{array}{l}\text { Derecelendirme } \\
\text { ölçeği (likert) }\end{array}$ & 25 & $21,93 \%$ & 22 & $19,30 \%$ & 28 & $24,56 \%$ & 28 & $24,56 \%$ & 11 & $9,65 \%$ \\
\hline $\begin{array}{l}\text { Dereceli Puanlama } \\
\text { Anahtarı (rubrik) }\end{array}$ & 30 & $26,32 \%$ & 19 & $16,67 \%$ & 29 & $25,44 \%$ & 27 & $23,68 \%$ & 9 & $7,89 \%$ \\
\hline Kontrol listesi & 24 & $21,05 \%$ & 18 & $15,79 \%$ & 38 & $33,33 \%$ & 25 & $21,93 \%$ & 9 & $7,89 \%$ \\
\hline Görüşme & 14 & $12,28 \%$ & 14 & $12,28 \%$ & 31 & $27,19 \%$ & 32 & $28,07 \%$ & 23 & $20,18 \%$ \\
\hline Gözlem & 4 & $3,51 \%$ & 7 & $6,14 \%$ & 33 & $28,95 \%$ & 43 & $37,72 \%$ & 27 & $23,68 \%$ \\
\hline Grup değerlendirmesi & 7 & $6,14 \%$ & 11 & $9,65 \%$ & 36 & $31,58 \%$ & 39 & $34,21 \%$ & 21 & $18,42 \%$ \\
\hline Akran değerlendirmesi & 10 & $8,77 \%$ & 14 & $12,28 \%$ & 30 & $26,32 \%$ & 43 & $37,72 \%$ & 17 & $14,91 \%$ \\
\hline Öz değerlendirme & 10 & $8,77 \%$ & 9 & $7,89 \%$ & 34 & $29,82 \%$ & 46 & $40,35 \%$ & 15 & $13,16 \%$ \\
\hline Kavram haritaları & 22 & $19,30 \%$ & 21 & $18,42 \%$ & 26 & $22,81 \%$ & 33 & $28,95 \%$ & 12 & $10,53 \%$ \\
\hline Poster & 14 & $12,28 \%$ & 14 & $12,28 \%$ & 29 & $25,44 \%$ & 41 & $35,96 \%$ & 16 & $14,04 \%$ \\
\hline
\end{tabular}




\begin{tabular}{llllllllllll}
\hline & $\begin{array}{l}\text { 1. Yeterli } \\
\text { değilim }\end{array}$ & 2 & & \multicolumn{2}{c}{3} & & 4 & & \multicolumn{2}{c}{$\begin{array}{l}\text { 5. Çok } \\
\text { yeterliyim }\end{array}$} \\
\hline & $f$ & $\%$ & $f$ & $\%$ & $f$ & $\%$ & $f$ & $\%$ & $f$ & $\%$ \\
\hline $\begin{array}{l}\text { Proje } \\
\text { Ürün seçki dosyas }\end{array}$ & 21 & $18,42 \%$ & 16 & $14,04 \%$ & 29 & $25,44 \%$ & 33 & $28,95 \%$ & 15 & $13,16 \%$ \\
(portfolyo) & 24 & $21,05 \%$ & 17 & $14,91 \%$ & 28 & $24,56 \%$ & 33 & $28,95 \%$ & 12 & $10,53 \%$ \\
Yazılı rapor & 16 & $14,04 \%$ & 19 & $16,67 \%$ & 27 & $23,68 \%$ & 33 & $28,95 \%$ & 19 & $16,67 \%$ \\
Günlük/Mektup & 8 & $7,02 \%$ & 22 & $19,30 \%$ & 29 & $25,44 \%$ & 33 & $28,95 \%$ & 22 & $19,30 \%$ \\
\hline
\end{tabular}

Bu tabloda da " 3 ” orta düzey bir yetkinliği ifade etmektedir. Buna göre 1-2 ve 3 orta düzey ve altında olan bir yetkinlik algısına işaret etmektedir. Tablodaki veriler incelendiğinde; yanıtların dağılımında orta düzey ve altında yetkinlik görülen maddelerin yüzdesel dağılımı $\% 34,21$ ile $\% 70,18$ arasında değişkenlik göstermektedir. En yetkin düşünülen yöntem ve tekniklerden ilk üçü "SoruCevap", "Boşluk tamamlama soruları", "Doğru yanlış soruları" iken en az yetkinlik görülen ölçme ve değerlendirme tekniklerinden üçü ise "Derecelendirme ölçeği (likert)", "Dereceli Puanlama Anahtarı (rubrik)" ve "Kontrol listesi”" şeklindedir.

Lider ve Lider Adaylarının Ölçme ve Değerlendirme Konusundaki Yeterlilik Algısı ile ilgili uygulanan anketin genel sonuçları bakımından, \%30 üzerinde yetkinlik kayıplarının büyük olduğu söylenebilir. Buna göre lider ve adayların bahsi geçen yetkinliklere yeterli düzeyde sahip olmadığı ifade edilebilir.

Grubun önemli bir kısmının eğitim sektöründen geldiği ve yine önemli bir oranda bu gibi eğitimleri almış oldukları görülmektedir. Buna karşın Tablo 11 ve Tablo 12'den hareketle yetkinlik algılarının görece düşük olduğu söylenebilir. Önemli bir kısmı öğretmen olarak görev yapan lider ve aday katılımcıların, yaratıcı drama süreçlerinde ölçme ve değerlendirmeden yararlanacak yetkinliğe sahip olmadıkları yönünde görüş bildirdikleri söylenebilir.

\section{Tartışma, Sonuç ve Öneriler}

Araştırma kapsamında gerçekleştirilen alan yazın tarama sonuçları, yaratıcı drama lider ve adaylarının ölçme değerlendirme konusundaki görüş ve profillerinin daha önce çıkartılmadığını göstermektedir. Ayrıca yaratıcı drama ve ölçme değerlendirme konusunda da sınırlı sayıda araştırma yapıldığını göstermektedir. Yurt dışı araştırmalara yönelik internet arama sonuçları da sınırlı sayıda kaynağa referans oluşturmakta ve ağırlıklı olarak sanat eğitimi bünyesinde ve performans değerlendirme çerçevesinde ele alınmaktadır. Yaratıcı drama liderinin mesleki yeterlilikleri arasında pek çok kaynakta belirtilen ölçme değerlendirme yöntem tekniklerinin bilinmesi ve kullanılması için liderlik programı içerisinde veya harici programlarla bu yeterliliğin desteklenmesi gerektiği ortaya çıkmaktadır. Araştırma bulguları lider ve lider adaylarının önemli bir kısmının yaratıcı drama liderliği/ eğitmenliği programı dişında da ölçme ve değerlendirme, nicel veya nitel araştırma yöntemleri konusunda eğitim aldığını göstermektedir. Lider adaylarının \% 76,3'ünün eğitim sektöründen geliyor olması bu sonucun nedeni olabilir. Karacaoğlu'nun (2008) gerçekleştirdiği ulusal ve uluslararası düzeyde öğretmen yeterlilikleri ile ilgili inceleme ve $\mathrm{AB}$ uyum sürecinde öğretmen yeterliliklerini inceleme çalışmasında, "öğrenmeyi, gelişimi izleme ve değerlendirme” öğretmen yeterlilikleri 
arasında yer almaktadır. Aynı çalışmada bu yeterlilik, öğretmenler tarafından kendilerini en az yeterli buldukları alan olarak ifade edilmiştir. Bu çalışmadan elde edilen bulgular ışığında da lider ve lider adaylarının ölçme ve değerlendirme araçları konusundaki yeterli düzeyde yetkin olmadıkları ifade edilebilir. Ayrıca lider ve lider adaylarının nitel ve nicel araştırma yöntemleri, örnekleme teknikleri, araştırma desenleri konularındaki yeterlilik algılarının büyük ölçüde orta düzey ve altında yer aldığ 1 söylenebilir.

Lider ve lider adayları yaratıcı drama atölyelerinde ağırlıklı olarak sonuç değerlendirmeye yer vermektedir. Ayrıca ağırlıklı olarak sözlü değerlendirme yapmaktadır. Buna karşın literatürde biçimlendirici değerlendirmenin öğrenen başarısına ve öğrenme alanına ilişkin olumlu katk1 sağladığını gösteren pek çok araştırma bulunmaktadır. Öte yandan araştırma bulguları, yaratıcı drama atölyelerinde gerçekleştirilen ölçme ve değerlendirme uygulamalarına ait sonuçların büyük ölçüde kayıt altına alınmadığı göstermektedir. Bu iki faktörün öğrenme düzeyinin yükseltilmesi üzerinde olumsuz etkisinin olabileceği söylenebilir.

Şişman'a (2012) göre öğretmenlik yeterlilikleri arasında sık değerlendirme yapma ve geri bildirim alma ile öğrencilere geri bildirim verirken yararlı bilgiler üzerinde durma, başarısızlığ 1 değerlendirmeme yer almaktadır (Akt. Tileği, 2014). Yaratıcı dramanın yöntem olarak kullanıldığ durumlarda yaratıcı drama lideri olarak öğretmen, ölçme sonuçlarını uygun teknikler kullanarak yorumlayabilmeli, öğrencilerin güçlü ve zayıf yönlerini belirleyerek geri bildirim sağlamalı ve gerekli önlemleri alabilmelidir. Karacaoğlu (2008) tarafından öğretmenlerin öğretme-öğrenme sürecinde, belirlenen yeterliliklere uygun sınıf içi öğretmen davranışlarını gösterme düzeylerini belirlemek üzere yapılan çalışmada, öğretmenlerin "Verileri analiz ederek yorumlama, öğrenciye gelişimi ve öğrenmesi hakkında geri bildirim sağlama" konusunda yetersiz oldukları ifade edilmiş ve öğretmenlik hizmet öncesi ve hizmet içi eğitimlerinde öncelik verilmesi önerilmiştir. Ancak bu araştırma lider ve lider adaylarının yaratıcı drama atölyelerinde gerçekleştirilen ölçme ve değerlendirme uygulamalarına ait sonuçlara ilişkin olarak büyük oranda geri bildirim vermediklerini göstermektedir.

Araştırma sonucunda yaratıcı drama alanında ölçme ve değerlendirme yöntem ve tekniklerinin kullanımına ilişkin yayın ve proje yapılması gerektiği görülmüştür. Bu bakımdan yaratıcı drama süreçlerinde ölçme ve değerlendirme konusunda yürütülen projeler desteklenebilir, teşvik edilebilir.

Katılımcıların dile getirdiği görüşlerden elde edilen bulgular yaratıcı drama süreçlerinde ölçme ve değerlendirme yöntem ve tekniklerinin kullanımı ile ilgili olarak yaratıcı drama lideri/ eğitmeni yetiştirme sertifika programında, program geliştirme çalışmalarının yapılmasına ihtiyaç olduğunu göstermektedir.

$\mathrm{Bu}$ ihtiyacı kısa vadede karşılamak amacıyla Çağdaş Drama Derneği birim çalışmaları içerisinde ölçme ve değerlendirme biriminin kurulması ve bu sayede yaratıcı drama özelinde ölçme ve değerlendirme uygulamalarının geliştirilmesi ve yaygınlaştııılması sağlanabilir. Daha ileri bir aşama olarak ölçme ve değerlendirmenin ayrı bir uzmanlık alanı olmasından ve geniş içeriğinden hareketle, "yaratıcı drama için ölçme ve değerlendirme" konusunda bir sertifikasyon programı geliştirilebilir veya konulu atölye düzenlenebilir. 


\section{Kaynakça}

Adıgüzel, Ö. (2013). Eğitimde yaratıcı drama. (3.Baskı). Ankara: Pegem Akademi.

Adıgüzel, Ö., Metinnam İ. ve Özen Z. (2014). Yaratıcı drama bibliyografyası. Ankara: Pegem Akademi.

Arts Education Assessment: An Overview. FOCUS On NAEP. (1998) Vol.2 No.4

Çalışkan, İ. Ö. (2008). Yaratıcı drama ile ölçme değerlendirmeye bakış. Ankara: Özel Doğaç Yayımlanmamış Yaratıc Drama Liderlik Programı Bitirme Projesi.

Ertürk, S. (1972). Eğitimde program geliştirme. Ankara: Yelkentepe Yayınları.

Karacaoğlu ,Ö. (2008). Avrupa Birliği uyum sürecinde öğretmen yeterlilikleri. Ankara: Ankara Üniversitesi Eğitim Bilimleri Enstitüsü yayımlanmamış doktora tezi.

Karadağ, E., Korkmaz, T., Çalışkan, N., Yüksel, S. (2008). Drama lideri olarak öğretmen ve eğitimsel drama uygulama yeterliği ölçeği: geçerlik ve güvenirlik analizleri. Gazi Eğitim Fakültesi Dergisi. Cilt 28. Say1 2., 169-196.

Karasar, N. (2012). Bilimsel araştırma yöntemi: kavramlar, ilkeler, teknikler. (12.Basım). Ankara: Nobel Yayın Dağıtım

Köksal, N. (2006). Eğitim programının ögeleri ve yaratıı drama. Yaratıcı Drama Liderlik Programı Bitirme Projesi. Ankara.

Köksal, N. (2007). Eğitim programları ve yaratıcı drama. Yaratıcı Drama Dergisi. Cilt 1. S.3-4, 179-189.

Okvuran, A. (2003). Drama öğretmeninin yeterlilikleri. Ankara Üniversitesi Eğitim Bilimleri Fakültesi Dergisi. Cilt 36. S.1-2, 81-87.

Özmen, A. (2006). İstatistik. Eskişehir. TC. Anadolu Üniversitesi Yayını No: 1448.

Şişman, M. (2012). Eğitimde mükemmellik anlayışıı. Ankara: Pegem

Tileği, H. (2014). İlkokul ve ortaokullarda görev yapan öğretmenlerin algılarına göre ögrretmen yeterlilikleri. Gaziantep: Zirve Üniversitesi yayımlanmamış yüksek lisans tezi.

Turgut, Prof. Dr. M. F. (1997). Eğitimde ölçme ve değerlendirme metotları. (10. Baskı). Ankara: Yargıcı Matbaasi.

Üstündağ, T. (1996). Yaratıcı dramanın üç boyutu. Yaşadıkça Ĕgitim. 49, 18-23.

Üstündağ, T. (1997). The Advantages of using drama as a method of education in elementary schools. Hacettepe Üniversitesi Eğitim Fakültesi Dergisi. 13, 89-94.

Üstündağ, T., Çalışkan, İ., Ö. (2010). Ölçme ve değerlendirme dersinde yaratıcı dramanın kullanılmasına ilişkin katılımcı görüşleri. Eğitim ve Bilim. Cilt 35, S.155, 37-48.

Yıldırım, A., Şimşek, H. (2013). Sosyal bilimlerde nitel araştırma yöntemleri. Ankara: Seçkin Yayıncılık. 


\section{EK 1: Yaratıcı Drama Lider ve Lider Adaylarının Ölçme Değerlendirme Konusundaki Görüşlerini Belirleme Anketi}

\section{YD LİDER VE LIDER ADAYLARININ ÖLÇME DEĞERLENDİRME KONUSUNDAKİ GÖRÜŞLERINII BELİRLEME ANKETİ}

Sayın Yaratıcı Drama Lideri/Lider Adayı,

$\mathrm{Bu}$ ankette sizlerin ölçme ve değerlendirme alanındaki yeterlilik algınız belirlenmeye çalışılmaktadır. Anket sorularını yanıtlayarak görüşlerinizi paylaşabilirseniz memnun olurum.

Teșekkürler

Yaratıcı Drama Eğitmenliği Programındaki seviyeniz
○ 5. Aşama
○ 6. Aşama (gönüllülük+raportörlük+proje)
○ Lider

Sektörünüz
O Eğitim
O Finans
○ Ticaret
○ Bilișim
○ Mühendislik
○ Sağlık
○ Hizmet sektörü
O Diğer:

Sektörünüzü "Eğitim” olarak seçtiniz...

Eğitim sektöründeki işiniz/uzmanlığınız
$\bigcirc \quad$ Anaokul öğretmeni
○ Sınıf öğretmeni
○ Yaratıı Drama Öğretmeni
○ Branş öğretmeni
O Özel öğretim öğretmeni
$\bigcirc \quad$ Rehber öğretmen
O Akademisyen
○ Uzman (EPÖ, EĞİTEK, EÖD)
O Öğrenci
O Diğer:

Daha Önce YD (Yaratıcı Drama) programı dışında ölçme değerlendirme konusunda eğitim aldınız mı?
O Evet
O Hayır

Daha önc e YD programı dışında nitel veya nicel araştırma yöntemleri konusunda eğitim aldınız mı?
Evet
O Hayır 
YD atölyelerinde (3 saatlik bir oturumda) değerlendirmelerinizin tümü için ayırdığınız/ayıracağınız ortalama toplam süre:
O $\quad 10 \mathrm{dk}$ ve daha az
○ $11-20 \mathrm{dk}$
○ $21 \mathrm{dk}$ ve daha az
O Hiç ayırmıorum

YD atölyelerini planlarken (3 saatlik bir oturumda) hangi değerlendirmelere yer veriyorsunuz?
○ Sadece ara değerlendirme
O Sadece genel (sonuç) değerlendirme
O Her ikisi de ama ara değerlendirme ağırlıklı
O Her ikisi de ama genel değerlendirme ağırlıklı
O Her ikisi dengeli
Hiçbiri

YD atölyeleri içerisinde (3 saatlik bir oturumda) hangisine daha sık başvurursunuz?
○ Sadece sözel ölçme değerlendirme
O Sadece sayısal ölçme değerlendirme
○ Her ikisi de ama sözel ölçme değerlendirme ağırlıklı
○ Her ikisi de ama sayısal ölçme değerlendirme ağırlıklı
O Her ikisi dengeli
O Hiçbiri

YD atölyelerinde yaptığınız ölçme değerlendirme sonuçları için bir izleme/takip kaydı (tablo, çizelge, not alma, kayıt vb.) tutuyor musunuz?
O Her zaman
○ Çoğunlukla
○ Bazen
○ Hiçbir zaman

YD atölyelerinde yaptığınız ölçme değerlendirmelerin sonucunda katılımcılara ne sıklıkla geri bildirim verirsiniz?
O Her zaman
○ Çoğunlukla
○ Bazen
O Hiçbir zaman

Bildiklerinizden/deneyimlerinizden hareketle aşağıdaki konular ile ilgili yetkinliklerinizi derecelendiriniz. Her satır için yanıt gereklidir.

$\begin{array}{lccccc}\text { 1. Yeterli değilim } & 2 & 3 & 4 & \text { 5. Çok yeterliyim } \\ \begin{array}{l}\text { Nitel araştırma } \\ \text { yöntemleri }\end{array} & 0 & 0 & 0 & 0 & 0 \\ \begin{array}{l}\text { Nicel araştırma } \\ \text { yöntemleri }\end{array} & 0 & 0 & 0 & 0 & 0 \\ \begin{array}{l}\text { Örnekleme teknikleri } \\ \text { Araştırma desenleri }\end{array} & 0 & 0 & 0 & 0 & 0 \\ \begin{array}{l}\text { Ölçme değerlendirme } \\ \text { araçları }\end{array} & 0 & 0 & 0 & 0 & 0\end{array}$


Yaratıcı Drama Lider ve Lider Adaylarının Ölçme ve Değerlendirme Konularındaki Profilleri ve Görüşleri

Bildiklerinizden/deneyimlerinizden hareketle, aşağıdaki ölçme değrelendirme yöntem ve teknikleri ile ilgili yetkinliklerinizi derecelendiriniz.

Her satır için bir yanıt gereklidir.

\begin{tabular}{|c|c|c|c|c|c|}
\hline & 1. Yeterli değilim & 2 & 3 & 4 & 5. Çok yeterliyim \\
\hline Soru-Cevap & 0 & 0 & 0 & 0 & 0 \\
\hline $\begin{array}{l}\text { Boşluk tamamlama } \\
\text { soruları }\end{array}$ & O & O & $\mathrm{O}$ & $\mathrm{O}$ & O \\
\hline $\begin{array}{l}\text { Kisa veya uzun cevaplı } \\
\text { sorular }\end{array}$ & O & O & $\mathrm{O}$ & $\mathrm{O}$ & O \\
\hline Çoktan seçmeli sorular & 0 & 0 & 0 & 0 & 0 \\
\hline Doğru yanlış soruları & 0 & 0 & 0 & 0 & 0 \\
\hline Eşleştirme soruları & 0 & 0 & 0 & 0 & O \\
\hline $\begin{array}{l}\text { Derecelendirme ölçeği } \\
\text { (likert) }\end{array}$ & O & 0 & $\mathrm{O}$ & 0 & 0 \\
\hline $\begin{array}{l}\text { Dereceli Puanlama } \\
\text { Anahtar (rubrik) }\end{array}$ & O & O & 0 & O & O \\
\hline Kontrol listesi & 0 & 0 & 0 & 0 & O \\
\hline Görüşme & O & O & $\mathrm{O}$ & $\mathrm{O}$ & 0 \\
\hline Gözlem & 0 & 0 & 0 & 0 & 0 \\
\hline Grup değerlendirmesi & O & O & $\mathrm{O}$ & $\mathrm{O}$ & O \\
\hline Akran değerlendirme & 0 & 0 & $\mathrm{O}$ & 0 & 0 \\
\hline Öz değerlendirme & 0 & 0 & 0 & 0 & 0 \\
\hline Kavram haritaları & 0 & 0 & 0 & 0 & 0 \\
\hline Poster & 0 & O & 0 & O & O \\
\hline Proje & 0 & 0 & 0 & 0 & 0 \\
\hline $\begin{array}{l}\text { Ürün seçki dosyası } \\
\text { (portfolyo) }\end{array}$ & O & 0 & $\mathrm{O}$ & O & O \\
\hline Yazılı rapor & 0 & 0 & 0 & 0 & 0 \\
\hline Günlük/Mektup & O & O & 0 & 0 & O \\
\hline
\end{tabular}


